\title{
A alteridade no enlaçamento social: uma leitura sobre o texto freudiano "O mal-estar na civilização"
}

\author{
Jacqueline de Oliveira Moreira \\ Pontifícia Universidade Católica de Minas Gerais
}

\begin{abstract}
Resumo
O presente trabalho define-se como uma revisão crítica do texto de Freud “O mal-estar na civilização”. Nossa leitura desse texto visa refletir sobre o problema da alteridade e sobre a teoria do enlaçamento social. O texto freudiano apresenta o encontro angustiante do eu com o outro. Realizamos uma pequena reflexão sobre a interpretação freudiana do mandamento cristão “Amarás a teu próximo como a ti mesmo” e sobre o problema moral do encontro com o outro, apontando para a dimensão trágica desse encontro. Finalizando, procuramos discutir a questão da culpa e da dívida como fundamentos do laço social.
\end{abstract}

Palavras-chave: alteridade; enlaçamento social; angústia; desamparo; castração

\begin{abstract}
The alterity in the social binding: a view of the Freudian text "Civilization and its Discontents". The following work can be defined as a critical revision of the text "Civilization and its Discontents", by Freud. Our view of the text aims to reflect on the problem of alterity and on the theory of the social binding. Freud's text presents the afflictive meeting of the self with the other. We will reflect on the Freudian interpretation of the Christian commandment “Thou shall love Thy neighbor as Thyself”, and on the moral problem of the meeting with the other pointing to the tragic dimension of this meeting. And, to finish, we will try to discuss the question of guilt and debt as basis of the social bond.
\end{abstract}

Key words: alterity; social binding; anxiety; abandonment; castration

\section{A dimensão trágica do encontro com a alteridade}

A pergunta que inaugura “O mal-estar na civilização” (Freud, 1930/1976) refere-se ao sentido e ao propósito da vida. Historicamente, a religião ofereceu respostas para essa questão, mas, na opinião de Freud, tais respostas situam-se no campo da ilusão. Devemos abandonar a pretensão de uma resposta universal, absoluta e totalizante, pois o propósito da vida só pode ser definido no campo individual.

Entretanto, Freud oferece uma possibilidade de colocação universal: os homens se esforçam para obter a felicidade, e esta é alcançada por meio da vivência de intensos sentimentos de prazer e diante da perspectiva da ausência de sofrimento. Fundamentando-nos na lógica interna da teoria psicanalítica, podemos dizer que o propósito da vida está submetido ao programa do princípio de prazer.

Não obstante, a perspectiva trágica que subjaz ao pensamento freudiano revelará um intenso ceticismo quanto à possibilidade de efetivação do prazer. A vivência do prazer só é possível em contraposição ao sofrimento. A verdadeira felicidade é repentina, toma-nos de surpresa, sendo, portanto, rara. Freud, em “O mal-estar na civilização”, convida Goethe para fundamentar sua posição: Alles in der Welt lässt sich ertragen, Nur nicht eine Reihe von schönen Tagen (Nada é mais difícil de suportar que uma sucessão de dias belos) (Goethe, 1810, apud Freud, 1930/1976, p. 95).

Já o sofrimento é mais comum, pois ele provém de três grandes fontes: (1) nosso próprio corpo; (2) o mundo externo; e (3) nossos relacionamentos com os outros homens. Para Freud, a maior fonte de sofrimento são nossos relacionamentos. Se o outro, por um lado, apresenta-se, em sua irredutível dimensão de pessoa, como o inferno corporificado, de outro lado, sem o encontro com ele, não haveria mundo humano. A constituição da esfera psíquica depende do encontro com a alteridade. Encontro esse sempre traumático.

No início da constituição do sujeito, este não reconhece o outro, pois vive no auto-erotismo uma situação de autosuficiência. Nesse caso, a frustração é baixa ou inexiste. Só quando o sujeito percebe sua dependência do outro a questão da frustração passa a ser crucial. Segundo Freud, o ego passa pela transformação de ego-prazer para ego-realidade, e 
as pulsões sofrem alterações que levam o auto-erotismo original ao amor objetal (Freud, 1911/1976, p. 284).

Assim, diante da iminência do sofrimento, via frustração, o princípio de prazer transforma-se em princípio de realidade. A frustração anuncia limites para o prazer, introduzindo a idéia de adiamento e até de não realização do desejo, e a felicidade, que antes se concentrava na realização tirânica do desejo, passa a buscar a esquiva do sofrimento.

Podemos observar em Freud, no que tange à discussão antropológica, o mesmo tipo de inquietude trágica presente em Schopenhauer; há uma continuidade no campo da história das idéias entre o psicanalista e o filósofo. Como bem observa Raikovic, parafraseando Kant: "Não teria feito Freud parte daquela mesma classe de 'contestadores' a que pertence Schopenhauer?” (Raikovic, 1996, p. 27).

Será “O mal-estar na civilização” o lugar privilegiado para explicitar a forte afinidade de Freud com o pensamento schopenhaueriano, e a discussão sobre a felicidade o tema que mais aproxima os dois autores? Em Schopenhauer, as páginas consagradas à apreciação da existência são conhecidas, sobretudo, pela descrição poderosa do sofrimento e da miséria humana. Seu pessimismo opera uma ligação indissolúvel que une vontade de vida e dor.

A vontade, autêntico significado do universo, se vê presa numa corrente de desejos e insatisfações infinitas, cristalizando, assim, a positividade do sofrimento como verdadeiro núcleo do mundo. O desejo infinito e a crescente insatisfação constituem a gênese do pessimismo schopenhaueriano. Esse filósofo desenvolve uma reflexão sobre a miséria humana, tentando revelar os fundamentos e analisar as conseqüências dessa condição miserável. Pois, a priori, independentemente da experiência concreta, a vida não admite nenhuma felicidade verdadeira.

No entanto, não é difícil comprovar, a posteriori, essa verdade filosófica na própria experiência. O mundo, metafisicamente falando, é um projeto vivo, que nunca se acaba nem se realiza efetivamente, pois o princípio último não é um ser, mas sim um desejo, uma tendência jamais satisfeita. O mundo é uma obra em eterno andamento. Em sua "Metafísica da natureza”, Schopenhauer descarta completamente a perspectiva teleológica:

A vontade, em todos os graus de sua manifestação, debaixo até em cima, tem falta total de uma finalidade última, desejar sempre, sendo o desejo todo o seu ser, desejo que não termina quando o objeto é alcançado, incapaz de uma satisfação última, e que para cessar tem necessidade de um obstáculo, uma vez que, por si mesmo, está lançado no infinito. (Schopenhauer, 1819/s.d., p. 407)

Todo desejo nasce de uma falta, de um estado de necessidade, portanto, de um sofrimento. Na medida em que se realiza um desejo, eis a felicidade. Ora, nenhuma satisfação dura, ela é apenas ponto de partida para um novo desejo. Para cada desejo satisfeito surge uma infinidade de outros desejos clamando por satisfação. Não há repouso, nem trégua, e sem repouso a verdadeira felicidade é impossível. Que- rer é essencialmente sofrer, porque o ponto de partida de todo querer é uma privação ou uma necessidade. E, como viver é querer, toda vida é essencialmente dor.

Por vezes pensamos que nossos males são acidentais, são contingenciais, mas a dor nos é dada na própria forma em que se manifesta a vida, não é um acaso. Freud parece compartilhar do pessimismo schopenhaueriano, ao afirmar: "ficamos inclinados a dizer que a intenção de que o homem seja 'feliz' não se acha incluída no plano da Criação” (Freud, 1930/1976, p. 95).

Freud parece reeditar o pensamento de Schopenhauer no que tange à problemática da felicidade. $\mathrm{O}$ pensador de Viena também considera que "a felicidade, no sentido restrito, provém da satisfação (de preferência, repentina) de necessidades represadas em alto grau, sendo, por sua natureza, possível apenas como manifestação episódica" (Freud, 1930/1976, p. 95).

Podemos, entretanto, encontrar mais um índice da herança pessimista de Schopenhauer no texto freudiano. Em "Psicologia de grupo e análise do ego" (Freud, 1921/1976), ao refletir sobre a natureza das relações emocionais entre os homens, ele recorda a famosa parábola schopenhaueriana dos porcos-espinhos. Todo o pessimismo schopenhaueriano quanto à possibilidade de uma estreita aproximação entre os homens é confirmado pela observação psicanalítica. Esta mostra que duas pessoas intimamente ligadas repetem o movimento de aproximação e distanciamento, figurado pelo amor e pelo ódio; da mesma maneira que os porcos-espinhos no frio se aproximam para o aquecimento mútuo, mas logo se distanciam pelo incômodo dos espinhos (Freud, 1921/1976, p. 128).

Freud, além de assumir uma posição trágica, do ponto de vista antropológico, considera, em seu discurso manifesto, a relação entre o eu e o outro como a expressão do inferno. Nas palavras do mestre:

Em resultado disso, o seu próximo é, para eles, não apenas um ajudante em potencial ou um objeto sexual, mas também alguém que tenta satisfazer sobre ele sua agressividade, explorar sua capacidade de trabalho sem compensação, utilizá-lo sexualmente sem seu consentimento, apoderar-se de suas posses, humilhá-lo, causar-lhe sofrimento, torturá-lo e matá-lo. Homo homini lupus. (Freud, 1930/1976, p.133)

Mas acreditamos que o texto freudiano possibilita outro olhar sobre o encontro do eu com a alteridade. Fundamentando a discussão sobre a relação entre o eu e o outro a partir da perspectiva da verdade do desamparo, teremos outros parâmetros para classificar o encontro intersubjetivo. O desamparo faz com que o eu perceba a importância inquestionável do outro para sua sobrevivência, instaurando, pois, a possibilidade de uma reflexão ética. Todavia, o discurso manifesto no texto "O mal-estar na civilização" apresenta o outro como destruidor, cristalizando uma visão trágica das relações intersubjetivas.

Ainda assim, podemos mostrar que no encontro intersubjetivo está em jogo não apenas uma, mas várias figu- 
ras de alteridade. Se Freud descreve o outro como representando um verdadeiro inferno para o eu é porque na relação daquele com o eu aparecem os fantasmas de toda sua história de subjetivação. Da mesma forma que o eu não pode ter uma relação com o outro sem que essa relação manifeste diferentes figuras de alteridade - que foram construídas em sua história existencial -, também o outro vive o mesmo impasse. Não existe relação pura entre dois outros-pessoas.

Apesar de Freud não se dedicar explicitamente ao tema da alteridade, podemos depreender da leitura de "O mal-estar na civilização” que o outro é o inferno porque não permite a total devoração pelo eu. E, em uma luta titânica, um deseja reduzir o outro ao mesmo, sem conseguir alcançar seu intento. Nesse combate cada um carrega em si as marcas de uma história, bem como determinadas cenas são registradas no inconsciente, no outro que habita o sujeito e que o mesmo desconhece.

\section{Alteridade e cristianismo: uma leitura freudiana da máxima ética cristã}

Sendo verdade que “O mal-estar na civilização” (Freud, 1930/1976) representa um texto-chave para uma possível discussão sobre a ética da psicanálise, também é verdade que, nas primeiras linhas do texto, Freud parece definir sua posição frente a essa mesma problemática, quando afirma:

É impossível fugir à impressão de que as pessoas comumente empregam falsos padrões de avaliação - isto é, de que buscam poder, sucesso e riqueza para elas mesmas e os admiram nos outros, subestimando tudo aquilo que verdadeiramente tem valor na vida. No entanto, ao formular qualquer juízo geral desse tipo, corremos o risco de esquecer quão variados são o mundo humano e sua vida mental. (Freud, 1930/1976, p. 81)

Poderíamos perguntar a Freud: o que tem verdadeiramente valor na vida? Qual seria o soberano bem? Neste ponto, Freud é preciso e fiel aos fundamentos de sua teoria, dizendo-nos: "Não seria possível formular qualquer juízo geral”. Fica, assim, registrada a dificuldade de se estabelecer um "bem universal e absoluto", e, conseqüentemente, surge um novo problema para a ética: como propor uma ética sem um princípio universal?

Podemos assinalar que essa pergunta não deve ser dirigida diretamente ao texto freudiano, uma vez que o autor não se dedicou a examinar detidamente os enigmas das éticas. No entanto, podemos encontrar algumas pistas da posição de Freud, analisando, por exemplo, sua interpretação acerca da máxima cristã "Amarás a teu próximo como a ti mesmo" e nela incluindo este outro mandamento: “Amarás os teus inimigos”. E não deixa de ser instrutivo comparar a interpretação freudiana desse preceito evangélico fundamental com as reflexões que Kant nos oferece sobre o mesmo tema.

Esperamos, desse modo, revelar as diferenças básicas entre os dois autores, bem como travar um diálogo entre as afirmações psicanalíticas e as de um representante eminente da tradição ética filosófica, já que será neste que encontraremos uma virada fundamental na história da ética. Esse filóso- fo irá propor uma ética formal, totalmente independente da experiência, uma filosofia moral pura. Assim, toda discussão ética depois de Kant relaciona-se direta ou indiretamente com suas posições éticas, seja para afirmá-las ou para apontar seus limites.

Comecemos com Kant. A filosofia do formalismo moral interpreta o mandamento cristão “Amarás o teu próximo como a ti mesmo, e mesmo o teu inimigo” como uma mensagem dirigida ao dever. Deus não está ordenando um amor sensível, mas sim um amor por dever, ou seja, um amor razoável. Nas palavras de Kant:

\footnotetext{
É sem dúvida também assim que se devem entender os passos das escrituras em que se ordena que amemos o próximo, mesmo o nosso inimigo. Pois que o amor enquanto inclinação não pode ser ordenado, mas o bem-fazer por dever, mesmo que a isso não sejamos levados por nenhuma inclinação e até se oponha a ele uma aversão natural e invencível, é amor prático e não patológico, que reside na vontade e não na tendência de sensibilidade, em princípios de ação e não em compaixão lânguida. E só esse amor pode ser ordenado. (Kant, 1786/1980, p. 114)
}

Subjacente a essa interpretação kantiana, encontra-se todo o fundamento de sua filosofia moral. Uma ação moral é aquela que está em conformidade com a lei e com a razão. Para que uma ação tenha o estatuto de ação moral, ela deve estar em conformidade com a "Lei Universal” ditada pela razão prática. Assim, devo proceder sempre de tal maneira que o princípio subjetivo do meu querer possa tornar-se um princípio objetivo, ou seja, que a máxima de minha ação se torne uma lei universal.

O que podemos perceber nesse processo é que o agir por dever é uma ação livre, na medida em que se autodetermina. A ação determinada por inclinações sensíveis não é livre, não é autônoma, pois é comandada por desejos. Em contrapartida, o dever é constituído em nós mesmos. A lei moral se dá a si mesma, isto é, se autodetermina como liberdade.

O reconhecimento da racionalidade em nós coincide com a percepção da liberdade. A lei moral é constitutiva da vontade; por isso a ação por dever é livre, se dá a si mesma. A dignidade do homem está na possibilidade de sua razão prática ser constitutiva de si mesma. A razão prática, para Kant, tem seu fim em si mesma, que é seu autodesenvolvimento e produção em direção à sua realização plena.

Entretanto, Kant sabe que o homem não é exclusivamente um ser razoável, embora ele deva ser razoável, e é precisamente neste ponto que se instaura a possibilidade do mal radical. Pois, ontologicamente, o homem é moralmente insuficiente para o bem, embora seja formalmente chamado para a conduta moral concreta. Com isso, Kant propõe uma cisão na realidade, que se divide entre fenômeno e noumeno, entre sensível e inteligível.

Uma cisão que, sendo insuperável do ponto de vista da razão, pode descortinar o horizonte da unidade, numa exigência apenas compreensível no âmbito da crença ou dos postulados da própria razão prática. Entretanto, essa cisão pode 
ser pensada como forma de se recusar a prevalência definitiva do mal e da violência. Num ser totalmente racional, não haveria espaço para o mal; por isso devemos crer na possibilidade de progresso da humanidade.

A progressão na consecução da plena conformidade com a lei moral é, portanto, característica da perfeição moral humana. (...) Esse progresso infinito só é possível sob o pressuposto de uma existência que dure até o infinito e de uma personalidade do mesmo ser razoável (a qual se chama imortalidade da alma). (Herrero, 1991, p.71).

Assim, se por um lado podemos compreender o formalismo moral kantiano como uma recusa da violência, na medida em que o sujeito ideal dessa moral é o próprio sujeito racional do iluminismo, por outro lado Kant também não poderia evitar de ver o mal radical que habita o homem, pois: "se quisermos compreender a necessidade e a existência de uma moral, é preciso admitir o mal radical, 'como uma escolha anterior a todas as escolhas, fonte de tudo aquilo que será querido pelo indivíduo temporal, fenomenal, observável'.” (Perine, 1987, p. 94).

Contudo, apesar de certas leituras que acentuam o caráter trágico da filosofia kantiana, esse filósofo se mantém otimista frente ao destino da humanidade, pois a concepção de homem subjacente à filosofia kantiana é a do ser racional, do ser que se autodetermina.

Assim, “amar a teu próximo como a ti mesmo, mesmo na figura de teu inimigo” é um dever para o ser razoável, pois essa ação poderá tornar-se uma máxima universal. O ódio e a violência, embora facilmente observáveis no mundo fenomênico, não são passíveis de universalização, uma vez que, se numa experiência de pensamento os universalizássemos, toda a humanidade seria destruída. Portanto, ainda que sejamos obrigados a reconhecer a presença do mal em nossa existência sensível, somos igualmente obrigados a recusar sua legitimidade no domínio da ética, no domínio da razão prática.

Vejamos agora a interpretação de Freud. Na primeira pontuação, ele nos diz que esse mandamento é uma das exigências ideais da civilização, ou seja, aquilo que se tem por horizonte. Explicitando melhor: uma exigência ideal é aquela que orienta as condutas, um marco referencial, mas que porta, em si, a impossibilidade de realização efetiva. Após essa consideração preliminar sobre a forma do mandamento, Freud começa a analisar o conteúdo do mandamento. A prescrição de “amar o próximo como a mim mesmo” seria possível? "Meu amor, para mim, é algo de valioso, que eu não devo jogar fora sem reflexão” (Freud, 1930/1976, p. 130).

Sem dúvida, uma das expressões mitológicas mais marcantes da teoria psicanalítica é a de Narciso, que se associa intimamente à de Édipo. Nesse ponto, Freud parece privilegiar o discurso do eu, em detrimento da percepção do outro. O amor que tenho por mim é meu maior bem. As pulsões do ego e as pulsões sexuais voltam-se todas para o mesmo objeto, o eu. E esse amor, que é tão valioso para a conserva- ção de minha vida, deveria direcioná-lo para outrem? Mesmo quando esse outro for um estranho? Devo amá-lo como amo a mim mesmo? Devo amar o próximo, mesmo aquele desconhecido, simplesmente porque é um habitante da Terra, como os escorpiões e as serpentes?

Essa tarefa, além de irrealizável, seria ofensiva. Amar um estranho como a mim mesmo desmerece o meu amor por mim e desconsidera os meus entes queridos. O estranho, além de não ser digno do meu amor, possuiria mais direito, na verdade, a minha hostilidade. O estranho é um não-eu, uma exterioridade absoluta; assim, ele "não hesitará em me prejudicar, caso tenha oportunidade” (Freud, 1930/1976, p. 131).

A meu ver, pode-se dizer que a lógica do raciocínio freudiano neste ponto segue o princípio da consciência culpada, da consciência julgadora. Projeta-se no outro uma ação que você faria, caso tivesse oportunidade. Mas isso não importa. O fundamental nesta discussão é que, para Freud, na base de todas as relações encontramos "Narciso"; o elemento motor e protótipo de todas as relações futuras é o narcisismo. Assim, para Freud, faria mais sentido se o mandamento fosse "Ama a teu próximo como este te ama” (Freud, 1930/1976, p. 132).

Entretanto, parece-nos que esse mandamento freudiano nos conduziria a um impasse, uma vez que nessa máxima caberia o mal. Essa lei sempre poderia ser utilizada como justificativa para a violência. Todavia, se isto é um problema para as teorias filosóficas sobre a moral, para o discurso do dever-ser, para a psicanálise, tal afirmação não seria propriamente problemática, pois a teoria psicanalítica, além de trabalhar com o sujeito cindido internamente entre dois grandes sistemas - inconsciente e consciência -, trabalha com o desejo e a agressividade. Para a psicanálise, o sujeito é determinado por desejos inconscientes que ultrapassam sua autonomia consciente.

Desejo e aparelho psíquico estão necessariamente associados, já que a gênese do aparelho psíquico é marcada pelo surgimento do desejo. No que tange à problemática da agressividade, devemos dizer, primeiramente, que esta é uma das acepções da pulsão de morte, que representa o que há de mais originário, fundamental e primitivo no aparelho psíquico.

O caráter de repetível, permanente e resistente a toda transformação atribuído ao aparelho psíquico é decorrente da pulsão de morte. É nesse sentido que Freud anuncia como a tendência mais primitiva do aparelho psíquico o retorno ao estado inorgânico. “A tensão que então surgiu no que até aí fora uma substância inanimada se esforçou por neutralizarse; dessa maneira surgiu o primitivo instinto: o instinto a retornar ao estado inanimado” (Freud, 1920/1976, p. 56).

Interpretações contemporâneas da pulsão de morte, como a de Renato Mezan (1987), vinculam essa idéia preferencialmente ao tema da violência. Para esse autor, com a pulsão de morte, a violência passa a ser tematizada constantemente e passa a ocupar posição central na problemática da psicanálise. 
Violência do desejo que se perpetua na repetição, violência do pai que se instala no superego, violência da castração que bloqueia o amor, violência da cultura que internaliza o tema, violência do conflito defensivo que irá capacitar o neurótico, violência, enfim, do próprio discurso do paciente, do verbo do analista, da realidade que impõe seu tributo e liquida as ilusões. (Mezan, 1987, p. 252)

Em termos antropológicos, o homem da psicanálise é um ser de desejos e de “pulsões” agressivas. Assim, a interpretação de Freud sobre a máxima cristã será fortemente marcada por essa concepção de homem.

Se afirmamos anteriormente que a problemática do narcisismo é fundamental na antropologia freudiana, agora devemos tentar relacioná-la com a problemática do desejo e da agressividade. A relação entre desejo e narcisismo parece não suscitar dúvidas. Mas a relação entre desejo e agressividade parece carecer de explicitação.

Narcisismo e agressividade estão ligados indissoluvelmente. A relação narcísica primordial se precipita numa concorrência agressiva, porque Narciso não consegue se apropriar de sua própria imagem, e, além disso, essa imagem carrega em si a diferença. A imagem que Narciso deseja não é idêntica a ele mesmo.

Agressividade e alteridade parecem estar vinculadas, pois, na medida em que se percebe o outro-narcísico, a imagem do espelho, o não-eu rompe a bela identidade. O mesmo, o idêntico, não porta a violência, é o outro que destrói a bela e imaginária harmonia. E como a paixão narcísica é um investimento numa imagem, no outro de si mesmo, então abre-se o espaço para a violência. “Todo amor por si mesmo traz o germe do ódio a si mesmo e ao outro” (Costa, 1989, p. 143).

É nesse ponto que se insere a outra colocação de Freud sobre o mandamento. A máxima cristã está fadada ao malogro, porque os homens não são criaturas gentis, são por natureza seres agressivos. "Os homens não são criaturas gentis que desejam ser amadas e que, no máximo, podem defender-se quando atacadas; pelo contrário, são criaturas entre cujos dotes instintivos deve-se levar em conta uma poderosa quota de agressividade” (Freud, 1930/1976, p. 133).

A civilização tem de lançar mão de um gigantesco esforço para estabelecer os limites para a agressividade. O mandamento ideal de amor ao próximo é negativamente justificado pelo fato de nada ir tão fortemente contra a natureza original do homem.

Enfim, a última ponderação de Freud sobre o mandamento diz respeito, novamente, à forma. As leis universais criam sérios problemas, devido, de um lado, à impossibilidade de se fazer uma afirmação universal no campo da moralidade, e, de outro, ao desconhecimento das leis universais pelo aparelho psíquico. A pretensão de universalidade concretiza-se, então, como arbítrio e como nova forma, sutil, mas efetiva, de violência. Uma violência que se exerce justamente em nome dos ideais mais elevados. Segundo Freud, tal fato ocorre pois: o comportamento dos seres humanos apresenta diferenças que a ética, desprezando o fato de que tais diferenças são determinadas, classifica como "boas” ou “más”. Enquanto essas inegáveis diferenças não forem removidas, a obediência às elevadas exigências éticas acarreta prejuízos aos objetivos da civilização, por incentivar o ser mau. (Freud, 1930/1976, p. 132)

Entretanto, Freud propõe uma definição universal de uma ação má, que se refere àquela ação que pode ter como conseqüência a perda do amor do outro. Assim, quando o ponto de partida da discussão sobre a relação eu/outro é o narcisismo primário, o ego ideal aposta na impossibilidade do reconhecimento do outro. Porém, em contrapartida, quando a discussão é fundamentada no desamparo, anuncia-se o encontro, o reconhecimento e o respeito à alteridade, entrando em cena o narcisismo secundário, o ideal do ego, que se constitui em referência ao outro. Nesse caso, amar o outro como a si mesmo é uma exigência que possibilita a existência, é uma questão de afirmação da própria vida.

O mandamento cristão parece-nos um modelo exemplar do outro-abstrato, de uma lei que encarna uma exterioridade alteritária, e que só faz sentido na medida em que é mediatizado por outros personificados em sujeitos não assimiláveis pelo desejo e, assim, coloca uma lei constitutiva e ordenadora da vida humana. Quando Freud propõe o preceito de “amar o próximo como este te ama”, ele está trazendo para a discussão todas as figuras de alteridade. Pois o eu é constituído nessa rica relação com as diferentes figuras de alteridade. Assim, não é possível falar do eu sem o outro; o eu é o outro. O amor que tem por mim é, portanto, devedor do outro.

Freud não propõe outro mandamento, pois este se situa no campo do horizonte ideal, do dever-se; a psicanálise propõe uma reflexão sobre o possível para condições trágicas do humano. Podemos situar o mandamento cristão e a proposta de Freud no campo de Eros, pois visa à combinação do diferente e, portanto, aparece como possibilidade de encontro com a alteridade. O verbo combinar, como revela Figueiredo (1999), remete-nos à diferença, porque os iguais não se combinam, somam-se. Nesse sentido, Eros pode ser vinculado à vida porque combina diferentes, é dependente da alteridade.

\section{Laço social e laço libidinal: culpa e dívida na base da cultura}

A introdução do conceito de pulsão de morte aponta para a perspectiva que vê a vida não como valor instituído originariamente ou como verdade em si, mas como algo a ser conquistado, uma verdade para si e para o outro, um processo de vir-a-ser. E mais: a discussão sobre a pulsão de morte introduz uma concepção antropológica que pensa o homem com uma inclinação para a agressividade. Segundo Freud (1930/1976), este abrigaria uma disposição instintiva e original para a agressividade.

Essa concepção trágica do humano colocará a vida e a civilização como projeto de Eros, que deve desafiar as "tendências mortíferas” originárias da pulsão de morte. O processo de criação da civilização pode ser descrito como uma bus- 
ca do homem para suprir suas necessidades (Ananke) e para garantir o laço afetivo-sexual (Eros), sendo assim imprescindível o controle da agressividade, do potencial destrutivo, enfim, da própria pulsão de morte.

Mas Eros também deve ser controlado em seu excessivo projeto de ligação e vinculação. Isso porque o excesso da ligação contém em si a morte por falta de espaço para a circulação e o movimento; constitui uma forma de engessamento, e a vida exige o espaço da falta para a movimentação das peças. Assim, "os excessos libidinosos e os excessos destrutivos colocam permanentemente a cultura em xeque” (Figueiredo, 1999, p. 32).

Como controlar o potencial originário do homem para a agressividade? O processo civilizatório exige a formatação e contenção do quantum pulsional. A pulsão sexual na sua face demoníaca também deve ser contida. A cena edípica traduz teoricamente a contenção da sexualidade através da proibição do incesto. Mas a vivência do Édipo também possibilitará a contenção da hetero-agressividade através do superego. A triangulação edípica introduz a possibilidade de encontro com a alteridade. O reconhecimento do outro como fundamental na minha constituição psíquica e na garantia da vida biológica conduz à necessidade de respeito e preservação do laço vital que une o eu e o outro.

Assim, a agressividade dirigida a outrem deve ser introjetada, e nesse processo ocorrerá uma transformação da agressividade em sentimento de culpa. A percepção da alteridade se reinscreve, trazendo o sentimento de culpa por se ter desejado agredir o outro, não só na sua dimensão de pessoa, mas também em suas dimensões narcísica e objetal. Sinto-me culpado por desejar agredir aquele que no enlaçamento suporta comigo o desamparo.

A verdade do desamparo possibilita a percepção da dependência entre os sujeitos. O termo alemão Hilflösigkeit pode ser decomposto em três partes: Hilfe significa socorro, los pode ser definido por sem, keit é um terminação substantivadora. Assim, podemos traduzir Hilflösigkeit por insocorribilidade. O desamparo coloca o sujeito humano em uma condição de insocorribilidade, portanto, de dívida eterna.

Para Freud, a energia original que circula entre os sujeitos é a agressividade; por isso o laço social é garantido através da culpa, ou seja, da agressividade modificada a partir do encontro com a verdade do desamparo, que aponta para o outro como fim em si, e não como meio. Sem o encontro e o reconhecimento da alteridade, o eu sucumbiria no desamparo. A produção da civilização coloca a discussão ética como prioridade, na medida em que anuncia o encontro entre o eu e o outro como a base de sua constituição, como aquilo que especifica o humano.

A discussão ética na perspectiva freudiana descrita em “O mal-estar na civilização” traz a questão da culpa, da falta e da dívida simbólica como essenciais no encontro intersubjetivo. O sentimento de culpa aparece como uma das modalidades de relação com a alteridade. Assim, a culpa deve ser entendida como um fato estruturante na civilização.
Segundo Freud, o sentimento de culpa surge porque o sujeito fez realmente uma coisa má com outrem ou teve a intenção de fazê-lo. Na base da distinção entre o mau e o bom está a percepção do desamparo. A ação má é aquela que põe em risco o amor, que anuncia a possibilidade de perda do apoio e coloca o sujeito sozinho e, portanto, à mercê das três grandes fontes de sofrimento supracitadas. Nas palavras de Freud, "mau é tudo aquilo que, com a perda do amor, nos faz sentir ameaçados. Por medo dessa perda deve-se evitá-lo” (Freud, 1930/1976, p. 148).

Freud retoma o mito do pai primevo para compreender os enigmas da culpa. Após o assassinato do pai, os filhos poderão instituir uma cultura humana fundamentada na lei que proíbe o assassinato e o incesto, instaurando, pois, a figura do outro-abstrato. Cada indivíduo revive psiquicamente essa cena fundamental juntamente com o sentimento de culpa e a constatação da dupla proibição, sendo que esse revivescer não é consciente, mas ocorre no âmbito do outro-alteritário, a saber, o inconsciente.

Os novos sujeitos não cometeram o ato, mas tiveram a intenção de cometê-lo; basta a intenção para padecer a culpa, dilacerante enquanto experiência, mas estruturante em seu efeito. Calligaris (1990) chama a atenção para as aproximações em alemão, francês e português dos vocábulos culpa, falta e dívida.

Quando Lacan abre o seminário da Ética sobre a questão da faute, ele não está falando da culpabilidade psicológica, está falando da culpa, e o francês lhe permite um equívoco sensacional entre faute no sentido de onde eu errei e "faute" no sentido de carência. (Calligaris, 1990, p. 20)

Assim, a culpa surge da percepção da carência, do desamparo. Devo sentir-me culpado por desejar o mal para o outro-pessoa, pois na minha condição de desamparo dependo de sua proximidade. Desse modo, instaura-se a questão da dívida simbólica, o que me vincula eternamente ao outropessoa. Em alemão, Schuld refere-se tanto à culpa quanto à dívida. Segundo Calligaris (1990), “o problema entre dívida e culpa é muito antigo; no pater noster em latim o que é pedido a Deus é que perdoe nossas dívidas” (Calligaris, 1990, p. 20).

Freud utiliza a expressão "sentimento de inconsciente de culpa definido" como uma tensão entre o ego e o superego, que difere do sentimento de culpa consciente, porque neste a tensão acontece entre o ego e o ideal do ego. No sentimento de culpa consciente encontramos uma condenação do ego a partir de um horizonte de idealidade. O sentimento de culpa inconsciente aparece, sobretudo, na neurose obsessiva e na melancolia.

No último caso, o ego não arrisca contrapor-se ao superego; o ego admite a culpa e se submete ao castigo, pois o objeto alvo do ódio do superego foi internalizado e identificado com o ego. Freud revela que "grande parte do sentimento de culpa (Schuldgefühl) deve permanecer inconsciente, pois a origem da consciência (conscience) acha-se intimamente vinculada ao complexo de Édipo, que pertence ao inconsciente” (Freud, 1923/1976, p. 68). Dessa forma, todo ho- 
mem é muito mais imoral do que crê. Todo homem carrega a culpa pela cena edípica.

Nesse sentido, Freud levanta a hipótese de que o aumento do sentimento de culpa pode transformar as pessoas em criminosas, ou seja, criar um substituto para a cena edípica que se vincule à representação da culpa. Ao invés de o sujeito se sentir culpado por seus desejos incestuosos, ele atua na realidade e produz uma nova representação ideativa para se associar à representação afetiva "inconsciente” de culpa. Na tensão entre o ego e o superego, o primeiro atua na realidade através de infrações para produzir uma culpa visível ao superego punitivo.

Esse processo de atuação pode ser contabilizado na fatura da pulsão de morte; como revela Freud, "o superego é uma cultura pura de pulsão de morte” (Freud, 1923/1976, p. 69). Existe algo de destrutivo na tirania superegóica, sobretudo na melancolia e na neurose obsessiva. Para conter a auto-destrutividade superegóica, podemos fundir a pulsão de morte com a pulsão de vida ou desviá-la para o mundo externo na forma de agressividade. Assim, podemos dizer que existe uma dinâmica entre auto-agressividade e heteroagressividade. Segundo Freud, "quanto mais um homem controla sua agressividade, mais intensa se torna a inclinação de seu ideal à agressividade contra seu próprio ego" (Freud, 1923/1976, p. 71).

Nesse sentido, podemos pensar que, quanto mais um homem libera sua agressividade, menor se torna sua autoagressividade e mais inócuo se torna o sentimento de culpa na manutenção da conduta moral. Freud, em sua primeira reflexão sobre a guerra, datada de 1915, revela que o Estado libera a prática do mal em situação de guerra, e, na medida em que há um relaxamento de todos os laços morais entre os indivíduos coletivos da humanidade, ocorre uma repercussão sobre a moralidade dos indivíduos, "pois nossa consciência não é o juiz inflexível que os professores de ética declaram, mas é, em sua origem, 'ansiedade social', e nada mais” (Freud, 1915/1976, p. 316). No texto em questão, Freud menciona rapidamente a influência do fator interno na conduta moral - isto é, na necessidade de amor -, mas desenvolve seu raciocínio acentuando a importância do fator externo na manutenção da moralidade. A “suscetibilidade à cultura” (Freud, 1915/1976), ou seja, à pressão do ambiente cultural imediato, e também à influência da história cultural de seus ancestrais transforma o egoísmo e a crueldade, sob influência do erotismo, da necessidade de amor, em conduta moral. Assim, essa suscetibilidade pode ser temporariamente desfeita pela situação de guerra.

Pensamos também na possibilidade de que o aumento da hetero-agressividade comum na guerra torna inócua a autoagressividade punitiva superegóica, que exerce importante função de guardiã da moral através do sentimento de culpa inconsciente, liberando, assim, os conteúdos do Id que não primam pela qualidade civilizatória (Freud, 1915/1976, p. 319).

A palavra inconsciente, referida ao sentimento de culpa, pode parecer uma confusão teórica, pois como podemos pensar em um afeto inconsciente se o destino do afeto não é o recalque? Na verdade, a resposta se encontra na dinâmica do substituto ideativo, pois, na medida em que se produz uma nova representação ideativa para se associar ao sentimento de culpa edípico, este, por sua vez, "se perde numa inconsciência”, ou seja, o afeto-culpa, que se tornou livre a partir do recalque da idéia de origem - a cena edípica -, perde seu conteúdo originário, tornando-se um sentimento de culpa inconsciente.

O sentimento não é inconsciente, o que é inconsciente é a representação ideativa que originalmente produziu a culpa, mas, como o sentimento de culpa está associado a uma nova representação, falamos, por um vício de linguagem, que o sentimento de culpa sobre a cena edípica é inconsciente.

Na primeira vez que Freud pensa em sentimento de culpa, ele utiliza a expressão consciência de culpa inconsciente (unbewusstes Schuldbewusstsein). No texto "Atos obsessivos e práticas religiosas” (Freud, 1907/1976), ao estudar o problema da compulsão nos obsessivos, ele levanta a hipótese de existir uma "consciência inconsciente de culpa” na base dos rituais.

Intriga-nos o fato de Freud ter optado pela expressão consciência de culpa inconsciente, ao invés de usar a consagrada expressão sentimento de culpa inconsciente. Talvez a utilização da expressão consciência de culpa inconsciente possa ser atribuída a características próprias do tema de Freud nesse texto, a saber, os obsessivos. Os neuróticos obsessivos tendem a racionalizar todos os sentimentos e ações; assim, seria mais próprio uma consciência de culpa inconsciente do que um sentimento de culpa inconsciente.

Nossa indagação, em termos teóricos, é vazia, porque as duas expressões possuem o mesmo significado, mas não podemos negar que a palavra consciência nos remete a uma problemática diferente da palavra sentimento. Consciência nos remete, a princípio, à idéia de responsabilidade. Parece interessante pensar nas distinções entre culpa e responsabilidade.

Segundo Souza (1996), a culpa é sustentada pelo assujeitamento aos ideais morais, impossíveis de serem atingidos pelo pobre ego pressionado pelo id e pelo superego. E a responsabilidade se refere à escolha do sujeito em responder por seus desejos inconscientes. Tanto em sentimento de culpa inconsciente quanto em consciência de culpa inconsciente, estamos tratando com um assujeitamento aos ideais morais, ou seja, uma pressão tirânica do superego sobre o ego.

Assim, o enlaçamento social é garantido pela energia libidinal que a princípio figurava como agressividade e que, diante da constatação do desamparo, transforma-se em culpa e dívida, revelando que sem o outro não existe o eu.

\section{Conclusão}

Podemos dizer, portanto, que Freud, no texto "O malestar na civilização”, apresenta uma visão pessimista no que tange à questão da relação entre o eu e o outro. Mas acreditamos que essa visão é decorrente de uma leitura que centra 
a reflexão em torno do conceito de narcisismo; ou seja, tomando como ponto de partida os apelos e desejos narcísicos do eu, o outro aparecerá como um obstáculo. E é a partir desse espírito pessimista e dessa leitura centrada no narcisismo que Freud se propõe, por exemplo, a interpretar o mandamento cristão de "amar o próximo como a ti mesmo".

No entanto, quando a leitura sobre a relação entre o eu e outro privilegiar o conceito de desamparo, poderemos rever essa visão pessimista. Pois o desamparo anuncia a dependência irremediável entre o eu e o outro. Nessa perspectiva, o encontro com a alteridade revelará sua face trágica. Isto porque o eu, na sua sede de poder, deseja reduzir o outro ao mesmo; mas a irredutibilidade é a marca da alteridade, produzindo um sofrimento sem saída no interior da relação, mesmo porque o sujeito não pode prescindir deste encontro. $\mathrm{O}$ encontro com o outro é um destino inexorável para o eu.

Nesse sentido, se pensarmos o mandamento cristão a partir da idéia de desamparo, poderemos descentrar o eu e assentar a leitura no tema do outro, anunciando, pois, a pertinência de tal mandamento. Assim, o mandamento figura como uma das possibilidades de contenção da força da pulsão de morte, que deve ser contida no âmbito social como forma de garantia da cultura, ainda que o preço seja o mal-estar do sujeito representado pela tirania do superego ou pela dor da dívida simbólica eterna para com o outro. Devo amar o próximo como a mim mesmo porque é este que me socorre no desamparo estrutural que habita meu ser.

\section{Referências}

Calligaris, C. (1990). Dívida, culpa e laço social. Manuscrito não-publicado, Belo Horizonte.

Costa, J. F. (1989). Psicanálise em contexto cultural. Rio de Janeiro: Zahar.

Figueiredo, L. C. M. (1999). Palavras cruzadas entre Freud e Ferenczi. São Paulo: Escuta.

Freud, S. (1976). Além do princípio de prazer. In Além do princípio de prazer, psicologia de grupo e outros trabalhos (edição standard brasileira das Obras
Psicológicas Completas de Sigmund Freud, Vol. XVIII, pp. 13-88). Rio de Janeiro: Imago. (Texto original publicado em 1920)

Freud, S. (1976). Atos obsessivos e práticas. In “Gradiva” de Jensen e outros trabalhos (edição standard brasileira das Obras Psicológicas Completas de Sigmund Freud, Vol. IX, pp. 119-134). Rio de Janeiro: Imago. (Texto original publicado em 1907)

Freud, S. (1976). Formulações sobre os dois princípios do funcionamento mental. In O caso de Schreber: artigos sobre técnica e outros trabalhos (edição standard brasileira das Obras Psicológicas Completas de Sigmund Freud, Vol. XII, pp. 273-286). Rio de Janeiro: Imago. (Texto original publicado em 1911)

Freud, S. (1976). O ego e o id. In O ego e o id, uma neurose demoníaca do século XVII e outros trabalhos (edição standard brasileira das Obras Psicológicas Completas de Sigmund Freud, Vol. XIX (pp. 13-86). Rio de Janeiro: Imago. (Texto original publicado em 1923)

Freud, S. (1976). O mal-estar na civilização. In O futuro de uma ilusão, o malestar na civilização e outros trabalhos (edição standard brasileira das Obras Psicológicas Completas de Sigmund Freud, Vol. XXI (pp. 75-174). Rio de Janeiro: Imago. (Texto original publicado em 1930)

Freud, S. (1976). Psicologia de grupo e análise de ego. In Além do princípio de prazer, psicologia de grupo e outros trabalhos (edição standard brasileira das Obras Psicológicas Completas de Sigmund Freud, Vol. XVIII, pp. 89179). Rio de Janeiro: Imago. (Texto original publicado em 1921)

Freud, S. (1976). Reflexões para os tempos de guerra e morte. In A história do movimento psicanalítico, artigos sobre metapsicologia e outros trabalhos (edição standard brasileira das Obras Psicológicas Completas de Sigmund Freud, Vol. XIV, pp. 311-326). Rio de Janeiro: Imago. (Texto original publicado em 1915)

Herrero, F. X. (1991). História e religião em Kant. São Paulo: Loyola.

Kant, I. (1980). Fundamentação da metafísica dos costumes (coleção Os Pensadores). São Paulo: Abril Cultural. (texto original publicado em 1786)

Mezan, R. (1987). Freud: a trama dos conceitos. São Paulo: Perspectiva.

Perine, M. (1987). Filosofia e violência / sentido e intenção da filosofia de Eric Weil. São Paulo: Loyola.

Raikovic, P. (1996). O sono dogmático de Freud: (Kant, Schopenhauer, Freud). Rio de Janeiro: Jorge Zahar.

Schopenhauer, A. (s.d.). O mundo como vontade e representação (Trad. M. F. Sá Correia). Porto, Portugal: Rés (Texto original publicado em 1819)

Souza, N. S. (1996). Ética e clínica da psicanálise. In M. I. França (Org.), Ética, psicanálise e sua transmissão. Petrópolis: Vozes.

Jacqueline de Oliveira Moreira, doutora em Psicologia pela Pontifícia Universidade Católica de São Paulo, é professora no mestrado e no curso de graduação em Psicologia da Pontifícia Universidade Católica de Minas Gerais. Endereço para correspondência: Rua Congonhas, 161, Bairro São Pedro; Belo Horizonte, MG; CEP: 30330-100. Tel: (31) 3223-3951. E-mail: jackdrawin@yahoo.com.br 